\title{
$\beta$-carotene as a dietary factor affecting expression of genes connected with carotenoid, vitamin A and lipid metabolism in the subcutaneous and omental adipose tissue of beef cattle
}

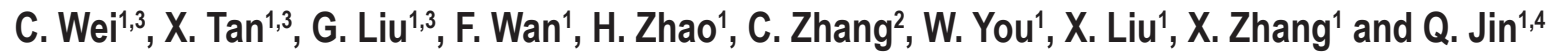 \\ ${ }^{1}$ Shandong Academy of Agricultural Sciences, Shandong Key Lab of Animal Disease Control and Breeding, Institute of Animal \\ Science and Veterinary Medicine, Jinan, 250100 Shandong Province, China \\ ${ }^{2}$ Shandong Normal University, College of Life Sciences, Jinan, 250014 Shandong Province, China
}

KEY WORDS: adipose tissue, beef cattle, $\beta$-carotene, gene expression, lipid metabolism

Received: 17 January 2019

Revised: 31 October 2019

Accepted: 18 February 2020

\begin{abstract}
Adipose tissue in meat, especially subcutaneous fat, is not appreciated by consumers as it is considered unhealthy. The effects of $\beta$-carotene $(\beta C)$ on the expression of ten genes related to carotenoid, vitamin A (VA) or lipid metabolism were evaluated in subcutaneous and omental (visceral) adipose tissue of Simmental crossbred steers receiving various $\beta C$ treatments $(0,600$, 1200 and $1800 \mathrm{mg} / \mathrm{d})$. Two carotenoid oxidative cleavage genes ( $\beta$-carotene15,15'-monooxygenase (BCMO1) and $\beta$-carotene-9',10'-dioxygenase (BCO2)) were up-regulated and three VA metabolic genes (retinoid $X$ receptor a $(R X R A)$, retinal reductase $(R A L D H)$ and lecithin-retinol acyltransferase $(L R A T))$ were down-regulated in subcutaneous and omental adipose tissues. Gene encoding peroxisome proliferator-activated receptor $\mathrm{y}$ (PPARG) involved in adipocyte differentiation and lipogenesis was down-regulated in both examined fat tissues. For the omental adipose tissue, the lipogenesis gene (fatty acid synthase (FAS)) and the two lipolysis genes (hormone-sensitive lipase (HSL) and adipose triglyceride lipase (ATGL)) were down-regulated, but another lipogenesis gene (acetyl-CoA carboxylase (ACC)) was up-regulated. First of all, the addition of $\beta C$ in the diet may inhibit the expression of the major adipogenesis gene - PPARG, and increase the expression of genes involved in $\beta C$ catabolism in adipose tissue of beef cattle. An effective $\beta C$ dose to regulate the expression of genes connected with carotenoid, VA and lipid metabolism would be at least $600 \mathrm{mg} / \mathrm{d}$.
\end{abstract}

\section{Introduction}

Adipose tissue is essential for whole-body energy homeostasis and can be affected by dietary nutrient levels and many organic compounds such as vitamins or amino acids. The fat of animal origin is not appreciated by consumers because it is considered to be unhealthy (Liu et al., 2014). However, the quantity and distribution of fat in the body, as well as fatty acid composition in the adipose tissue, are important contributors to various aspects of meat quality
(Siebert et al., 2006). Because of the consumer's increasing awareness of nutrition for healthcare on one hand and the need of reaching a certain level of fat in the meat to guarantee its organoleptic quality on the other, a better knowledge of adipogenesis in meat of farm animals would be desirable. Therefore, understanding adipose tissue physiology and regulating its development safely and effectively have become the important aspects of meat production.

Carotenoids, that play an important role as provitamin A and antioxidants, are C40 lipophilic 
pigments produced by photosynthetic organisms (Tourniaire et al., 2009). Among the hundreds of types of carotenoids, bovines mainly absorb $\beta$-carotene ( $\beta C)$ (Yang et al., 1992), which is also the main provitamin A carotenoid. Many but not all studies confirmed that the levels of $\beta C$ or vitamin $\mathrm{A}(\mathrm{VA})$ in the diet of beef cattle can influence fat deposition and meat quality (Yang et al., 1992; Siebert et al., 2006; Gorocica-Buenfil et al., 2007; Condron et al., 2014). Previous studies on $\beta C$ or VA effects in cattle were limited to their impacts on growth performance, carcass characteristics or other growth traits but rarely investigated the underlying mechanisms.

The $\beta$-carotene-15,15'-monooxygenase (BCMO1) is currently considered to be the key enzyme for the conversion of carotenoids (mainly $\beta C$ ) to retinoid. The product of $\mathrm{BCMO1}$, retinaldehyde (RAL), could be reduced to retinol $(\mathrm{ROH})$ by retinal dehydrogenases (RALDH) and then be esterified to form retinyl ester by lecithin-retinol acyltransferase (LRAT) (Shmarakov et al., 2013; Mezaki et al., 2016). Both RALDH and LRAT are important factors to predict the downstream molecules of BCMO1. Besides, the $B C M O 1$ promoter contains a peroxisome proliferator response element (PPRE), and when the peroxisome proliferator-activated receptor $\gamma$ (PPARG) dimerizes with the retinoid $\mathrm{X}$ receptor $\alpha$ (RXRA), it binds to this site. The natural ligands for mentioned above receptors, i.e., free fatty acids (FFA) for PPARs and retinoids for RXRs, can activate $B C M O 1$ expression (Boulanger et al., 2003; Gong et al., 2006).

A second carotenoid metabolizing enzyme, $\beta$-carotene-9',10'-dioxygenase (BCO2), catalyzes eccentric oxidative cleavage of carotenoids, such as $\beta \mathrm{C}$ and lycopene, at the $\mathrm{C}^{\prime}, \mathrm{C} 10^{\prime}$ double bonds (Gong et al., 2006). There are several other enzymes involved in lipid or carotenoids metabolism, among which acetyl-CoA carboxylase (ACC) and fatty acid synthase (FAS) participate in fatty acid biosynthesis, and hormone-sensitive lipase (HSL) and adipose triglyceride lipase (ATGL) catabolize stored triglycerides in the adipose tissue (Zimmermann et al., 2004; Lafontan and Langin, 2009).

To investigate the underlying mechanisms of $\beta C$ on adipose tissue development in different anatomical locations, we analysed the expression of $B C M O 1$, PPARG, RXRA, BCO2, RALDH and LRAT in subcutaneous and omental (visceral) adipose tissues, and the expression of FAS, ACC, HSL and ATGL in the omental adipose tissue. It will improve our understanding of how $\beta \mathrm{C}$ affects the meat quality and fat deposition processes in beef cattle.

\section{Material and methods}

The whole procedure with experimental animals was performed in strict accordance with guidelines (IACC20060101, 1 Jan, 2006) of the Institutional Animal Care and Use Committee of Institute of Animal Science and Veterinary Medicine, Shandong Academy of Agricultural Sciences (China).

\section{Animals and management}

To investigate the effects of supplementing $\beta C$ to the diet on fat deposition in the practical production of beef cattle, 120 continental crossbred (Simmental $\times$ local yellow cattle) steers (mean live weight: $381 \pm 26.01 \mathrm{~kg}$ ) were selected from feedlots and assigned randomly to four groups supplemented with different concentrations of $\beta \mathrm{C}$ per individual (i.e., 0, 600, 1200 or $1800 \mathrm{mg} / \mathrm{d}$ ) in standard basic daily ration. The composition and nutrient contents of concentrates (expressed as dry matter) are shown in Table 1. After the 15-day adaptation period, animals were restrained and fed individually during the whole 90-day experimental period. The concentrate feeding amount was controlled to $1 \%$ body weight of the steers to meet energy and major nutrients provision of the diet at about 1.3 times of maintenance requirements of beef cattle (Feng, 2000), and was adjusted once a month according to the steer's weight. Cattle were fed twice daily (06:00 and 16:00) and each dose of $\beta C$ was weighed every day for each animal, mixed with concentrate and split between two feeds. For more details about animals and management see Jin et al. $(2015 ; 2016)$.

Table 1. Composition and nutrient contents of concentrates (expressed as dry matter)

\begin{tabular}{llll}
\hline $\begin{array}{l}\text { Ingredients } \\
\text { Maize }\end{array}$ & $\begin{array}{l}\text { Content, } \\
\%\end{array}$ & $\begin{array}{l}\text { Nutritional } \\
\text { ingredient }\end{array}$ & $\begin{array}{l}\text { Nutrient } \\
\text { level, \% }\end{array}$ \\
$\begin{array}{l}\text { Wheat bran } \\
\text { Maize skin }\end{array}$ & 11.7 & $\begin{array}{l}\text { Dry matter (DM) } \\
\text { Crude protein (CP) }\end{array}$ & $\begin{array}{l}80.63 \\
15.80\end{array}$ \\
& 12.0 & $\begin{array}{l}\text { Net energy }\left(\mathrm{NE}_{\text {mf }}\right)^{2}, \\
\text { MJ/kg DM }\end{array}$ & 11.78 \\
Soybean meal & 9.9 & Calcium (Ca) & 1.44 \\
Palm meal & 20.6 & Phosphorus (P) & 0.84 \\
CaHPO & & & \\
Limestone & 1.7 & & \\
Sodium bicarbonate & 1.7 & & \\
NaCl & 2.2 & & \\
Premix ${ }^{1}$ & 1.7 & & \\
\hline
\end{tabular}

${ }^{1}$ The premix contained the following components per kg of concentrate: IU: vitamin A 1,250, vitamin $D_{3} 270$, vitamin E 5; mg: manganese 3,060, zinc 14,280 , iron 3,170 , copper 3,040 , selenium 100 , iodine 180 , cobalt $40 ;{ }^{2} \mathrm{NE} \mathrm{mf}_{\mathrm{f}}$ was a calculated value, while other values were measured 


\section{Adipose tissue sampling}

Ten randomly selected individuals from each group were slaughtered in a commercial slaughterhouse at the end of the 90-day experimental period. Fat samples from omental (visceral) and subcutaneous adipose tissue taken between the $12^{\text {th }}$ and $13^{\text {th }}$ ribs were collected into sterile tubes and stored in liquid nitrogen for further analysis of gene expression. All ten subcutaneous and omental fat samples from each group were used for mRNA level analysis, and three randomly selected from each group for protein determination.

\section{Western blot analysis}

The protein expression levels of BCMO1, PPAR $\gamma$ and RXR $\alpha$ were analyzed by Western blot. Briefly, adipose tissue samples were frozen in liquid nitrogen and homogenized using radio immunoprecipitation assay (RIPA) buffer. For $50-100 \mathrm{mg}$ of tissue, $0.5-1.0 \mathrm{ml}$ of RIPA buffer was added. The homogenate was transferred to a $1.5-\mathrm{ml}$ centrifuge tube and disrupted by ultrasonication on ice four times, each for $30 \mathrm{~s}$ at $100-200 \mathrm{~W}$. The mixture was centrifuged at $12000 \mathrm{~g}$ at $4{ }^{\circ} \mathrm{C}$ for $10 \mathrm{~min}$ and the total protein in the supernatant was collected. The details about the Western blot analysis have been described previously by Liu et al. (2018). Signals were detected with chemiluminesence method using the eECL Western Blot Kit (CoWin Biosciences, Inc., Beijing, China), and the images were acquired by GE ImageQuant LAS 500 imaging system (GE Healthcare Life Sciences, Uppsala, Sweden). Relative quantities of proteins were determined

Table 2. Primer sequences of genes selected for $\mathrm{QPCR}$ analysis

\begin{tabular}{|c|c|c|c|}
\hline Gene & Primer $\left(5^{\prime} \rightarrow 3^{\prime}\right)$ & Accession number & Product length, bp \\
\hline BCM01 & $\begin{array}{l}\text { Forward: GGCTTACATTCGGGGTGTGA } \\
\text { Reverse: CGTCCTTCGGTCGATGATGT }\end{array}$ & NM_001024559.1 & 88 \\
\hline PPARG & $\begin{array}{l}\text { Forward: CACCACCGTTGACTTCTCCAG } \\
\text { Reverse: ATACAGGCTCCACTTTGATTGC }\end{array}$ & NM_181024.2 & 140 \\
\hline$R X R A$ & $\begin{array}{l}\text { Forward: CTCAATGGTGTCCTCAAAGTG } \\
\text { Reverse: TCAGGCAGTCCTTGTTGTCC }\end{array}$ & NM_001304343.1 & 199 \\
\hline $\mathrm{BCO} 2$ & $\begin{array}{l}\text { Forward: GAACGGAGCAACTGCACATC } \\
\text { Reverse: TGTCTCCCCAGGGTCAGATT }\end{array}$ & NM_001101987.2 & 133 \\
\hline RALDH & $\begin{array}{l}\text { Forward: TACATCGCTGCACCCCAAAT } \\
\text { Reverse: TCCCCATTTTGTACGTCCCG }\end{array}$ & XM_005212080.4 & 185 \\
\hline LRAT & $\begin{array}{l}\text { Forward: CCTGACGCACTATGGCATCT } \\
\text { Reverse: TGAGACGCTTGTTGGAGACC }\end{array}$ & NM_177503.2 & 122 \\
\hline FAS & $\begin{array}{l}\text { Forward: GTGGGCTTGGTGAACTGTCT } \\
\text { Reverse: AGGACTTCGGGTCTGTCTCA }\end{array}$ & NM_001012669.1 & 112 \\
\hline$A C C$ & $\begin{array}{l}\text { Forward: AACGCAGGCATCAGAAGATT } \\
\text { Reverse: CGCACTCACATAACCAACCA }\end{array}$ & NM_174224.2 & 119 \\
\hline$H S L$ & $\begin{array}{l}\text { Forward: TGGGTTTCCAGTTCACACCT } \\
\text { Reverse: GATGCCAGTCTCGTTTCGTT }\end{array}$ & NM_001080220.1 & 101 \\
\hline ATGL & $\begin{array}{l}\text { Forward: TGTTCCCCAAGGAGACGAC } \\
\text { Reverse: GCCACGCCGATATGGTAGAC }\end{array}$ & FJ798978.1 & 76 \\
\hline ACTB & $\begin{array}{l}\text { Forward: CAGCAAGCAGGAGTACGATG } \\
\text { Reverse: AGCCATGCCAATCTCATCTC }\end{array}$ & NM_173979.3 & 137 \\
\hline
\end{tabular}

using Image-Pro Plus software (Media Cybernetics, Inc., Sliver Spring, MD, USA) by analyzing the sum density of each protein band image. The quantity of $\beta$-actin was used as an internal control. The density value of each sample was normalized to its $\beta$-actin density value to obtain its relative quantity value. The relative quantities of target proteins in the control group were set as one, and the values in $\beta C$ treatment groups were expressed relative to this quantity. lows: anti-BCMO1 polyclonal antibodies (1:200, sc-163736; Santa Cruz Biotechnology, Inc., Santa Cruz, CA, USA), anti-PPAR $\gamma$ polyclonal antibodies (1:400, NB120-19481; Novus Biologicals, Littleton, CO, USA), anti-RXR $\alpha$ monoclonal antibodies (1:1000, LS-C80051; LifeSpan BioSciences, Inc., Seattle, WA, USA), and anti- $\beta$-actin monoclonal antibodies (1:1000, 4970S; Cell Signaling Technology, Inc., Beverly, MA, USA).

\section{RNA extraction and qPCR}

Total RNA was isolated from fat tissues samples using the Trizol reagent (Invitrogen, Carlsbad, CA, USA). For each sample, $1 \mu \mathrm{g}$ of total RNA was used for first-strand cDNA synthesis as previously described (Liu et al., 2009). Real-Time PCR (qPCR) primers were designed and synthesized (Biosune, Shanghai, China) to assay differentially expressed genes (Table 2). Because of its stability among different adipose tissues (Schoof et al., 2004), the gene encoding $\beta$-actin (ACTB) was used as the housekeeping gene, and its $\mathrm{Ct}$ values in different tissues were expressed stably at $17-18$ in the present study.
The primary antibodies were chosen as fol- 
qPCR was performed using a real-time thermocycler (Light Cycler 480; Roche, Mannheim, Germany) with a final reaction volume of $20 \mu \mathrm{l}$ containing SYBR Green I (Roche, Mannheim, Germany). The cycling conditions were as follows: $95{ }^{\circ} \mathrm{C}$ for $8 \mathrm{~min} ; 40$ cycles of $95^{\circ} \mathrm{C}$ for $10 \mathrm{~s}, 58^{\circ} \mathrm{C}$ for $20 \mathrm{~s}$ and $72{ }^{\circ} \mathrm{C}$ for $30 \mathrm{~s} ; 95^{\circ} \mathrm{C}$ for $5 \mathrm{~s}$ and $65^{\circ} \mathrm{C}$ for $1 \mathrm{~min}$. The $\mathrm{Ct}$ values were obtained and the gene expression levels relative to that of the $A C T B$ were determined using the $2^{-\Delta \Delta(\mathrm{Ct})}$ method (Livak and Schmittgen, 2001).

\section{Statistical analysis}

All data were analysed by one-way analysis of variance (ANOVA) using SPSS ver. 21.0 software (IBM, Inc., Armonk, NY, USA). Expression of all examined genes (BCMO1, RXRA, PPARG, BCO2, RALDH, LRAT, FAS, ACC, HSL and ATGL) and proteins (BCMO1, RXR $\alpha$ and PPAR $\gamma$ ) in the subcutaneous and omental fat samples were analysed to assess the effects of the supplemental $\beta C$ treatments. If ANOVA results were significant, Duncan's multiplerange test was performed for multiple comparisons, with $P<0.05$ accepted as statistically significant.

\section{Results}

\section{Gene and protein expression of BCMO1, PPAR $\gamma$ and $R X R \alpha$ in two different adipose tissues}

Compared to the group without $\beta \mathrm{C}$ addition, higher mRNA levels of $B C M O 1$ in both subcutaneous and omental adipose tissue were observed in all groups with $\beta \mathrm{C}$ treatment $(P<0.05$; Figures $1 \mathrm{~A}$ and 1D). The expression of PPARG in both examined adipose tissues was significantly decreased in the groups that received $\beta C$ supplementation $(P<0.05$; Figures $1 \mathrm{~B}$ and $1 \mathrm{E})$. The expression of $R X R A$ was decreased in subcutaneous and omental fat samples collected from beef cattle with additional $\beta C$ supplementation $(P<0.05$; Figures $1 \mathrm{C}$ and $1 \mathrm{~F})$.

The protein expressions of BCMO1, PPAR $\gamma$ and $\mathrm{RXR} \alpha$ in both subcutaneous and omental adipose tissue were consistent with the expression pattern of the corresponding gene (Figures 2 and 3 for subcutaneous and omental adipose tissue, respectively).

\section{Expression of genes involved in carotenoid metabolism in two different adipose tissues}

$B C O 2$ expression levels were higher in $\beta C$ supplemented groups than that in the control one for both subcutaneous and omental adipose tissues $(P<0.05$; Figures $4 \mathrm{~A}$ and $4 \mathrm{D})$.

The $R A L D H$ expression in subcutaneous fat was significantly lower in the group treated with $1200 \mathrm{mg} / \mathrm{d} \beta C$ than in the control and other supplemented groups $(P<0.05$; Figure $4 \mathrm{~B})$. In omental adipose tissue, $\beta C$ supplementation decreased the $R A L D H$ expression regardless used $\beta \mathrm{C}$ dose $(P<0.05$; Figure 4E).

The LRAT expression in subcutaneous adipose tissue was significantly decreased in all groups supplemented with $\beta C$ in comparison with the control group $(P<0.05$; Figure $4 C)$. In omental adipose
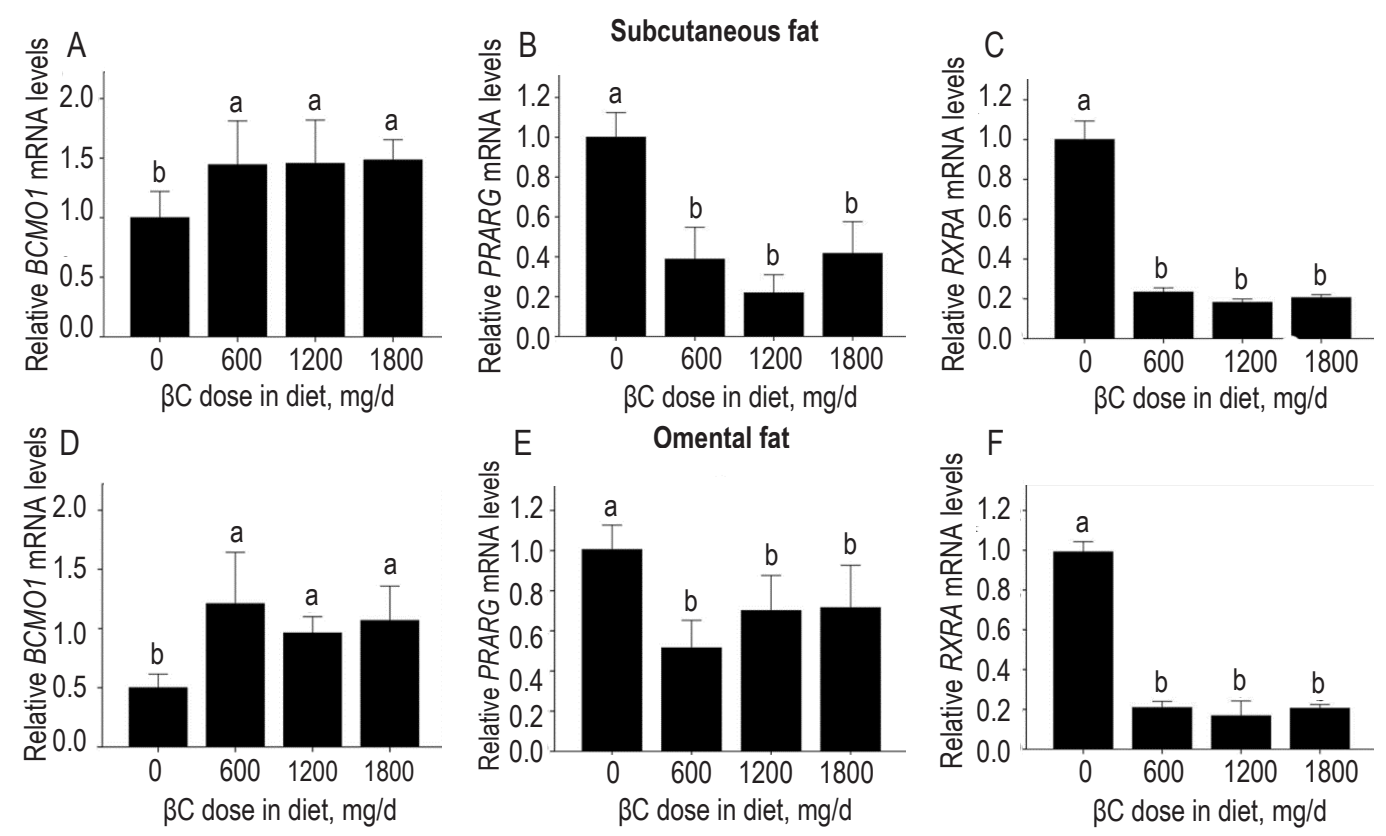

Figure 1. Expression of BCMO1 ( $\mathrm{A}$ and $\mathrm{D}), R X R A(\mathrm{D}$ and $\mathrm{E})$ and PPARG ( $\mathrm{C}$ and $\mathrm{F}$ ) in subcutaneous and omental fat, respectively, of beef cattle fed different doses of $\beta$-carotene $(B C)(0,600,1200$ and $1800 \mathrm{mg} / \mathrm{d})$; bars present means \pm standard error (SE), for 10 steers per group; $a-b-$ bars with different superscripts vary significantly $(P<0.05)$ 

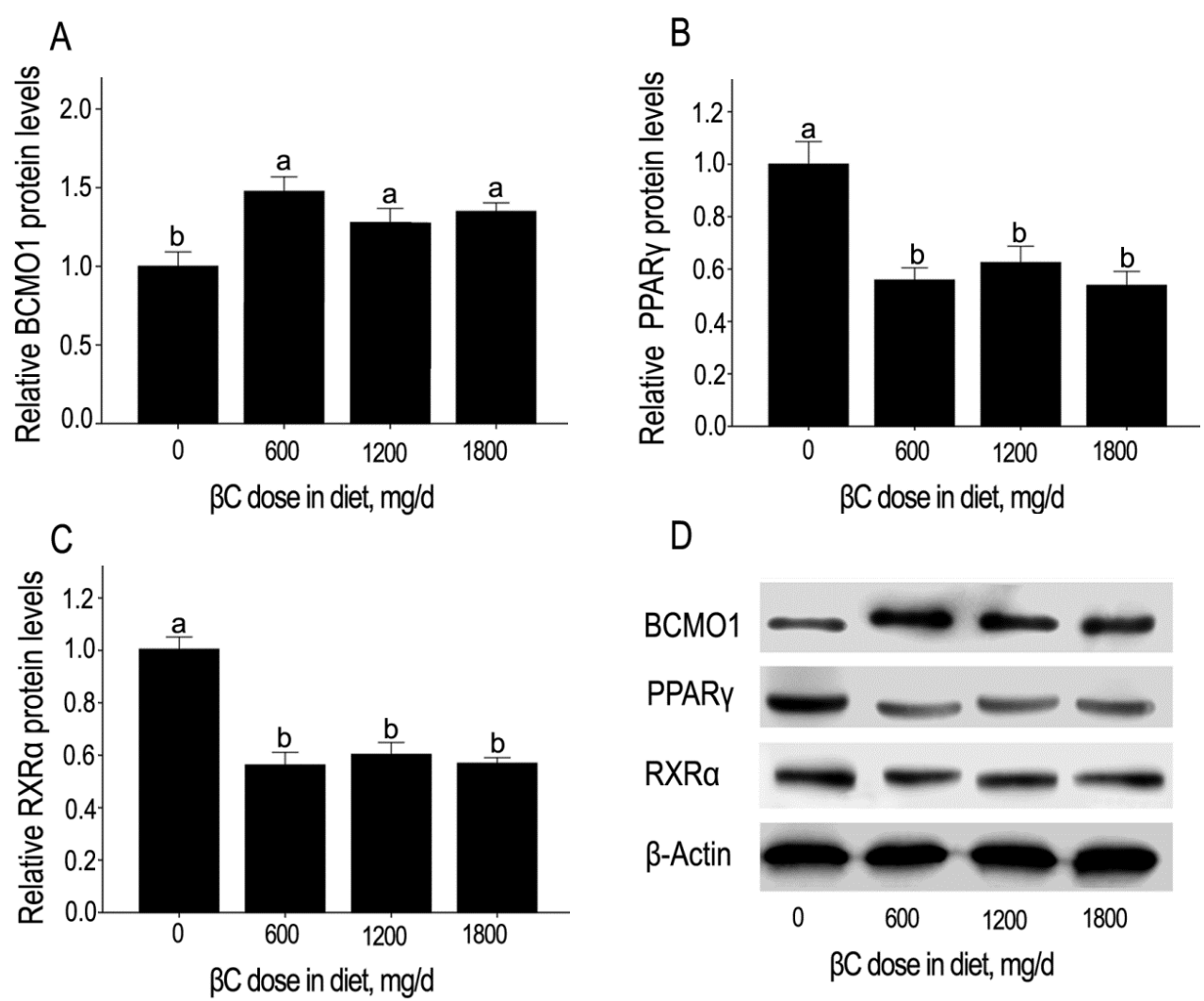

Figure 2. Expression of BCMO1 (A), PPARy $(B)$ and RXRa $(C)$ protein in subcutaneous fat of beef cattle fed different doses of $\beta$-carotene ( $\beta C$ ) $(0,600,1200$ and $1800 \mathrm{mg} / \mathrm{d})$; Figure A, B and C: bars present means \pm standard error (SE), for 3 steers per group; $a-b-$ bars with different superscripts vary significantly $(P<0.05)$; Figure $\mathrm{D}$ : bands present one representative sample from each group
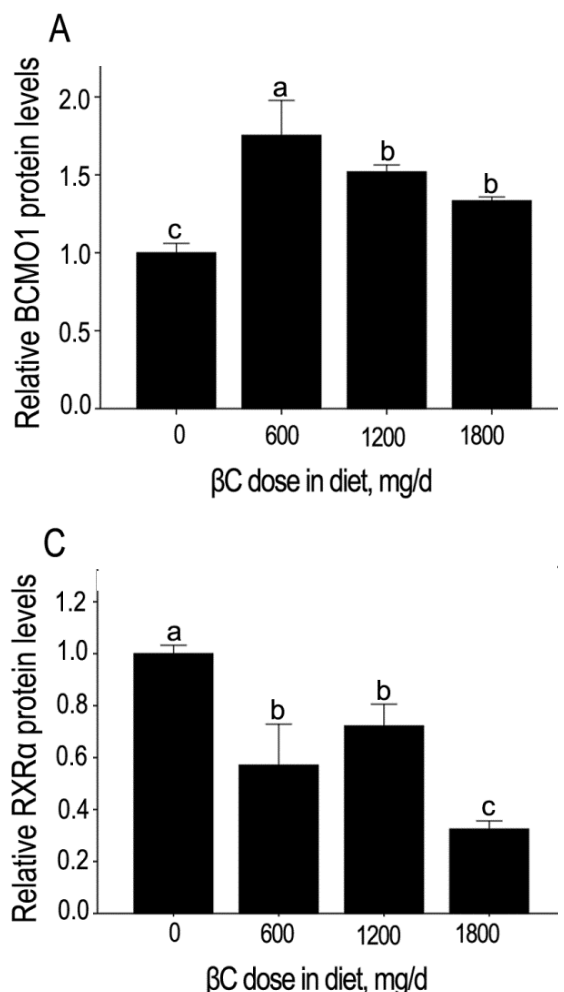

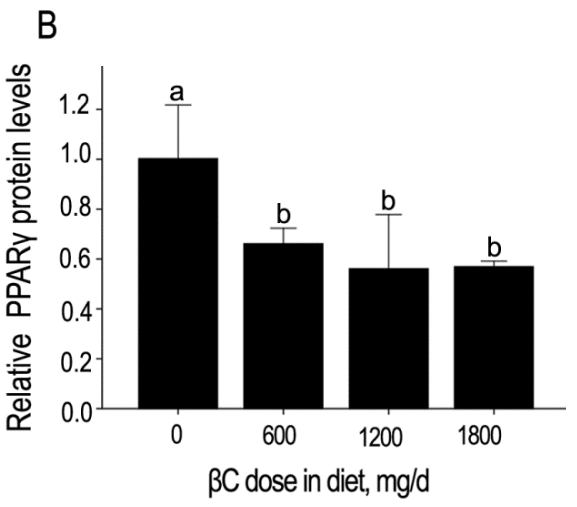

D

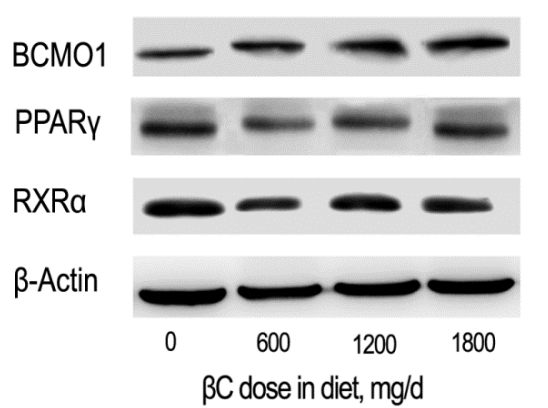

Figure 3. Expression of BCMO1 (A), PPARy (B) and RXRa (C) protein in omental fat of beef cattle fed different doses of $\beta$-carotene $(B C)(0,600$, 1200 and $1800 \mathrm{mg} / \mathrm{d})$; Figure A, B and C: bars present means \pm standard error (SE), for 3 steers per group; a-C - bars with different superscripts vary significantly $(P<0.05)$; Figure $D$ : bands present one representative sample from each group 

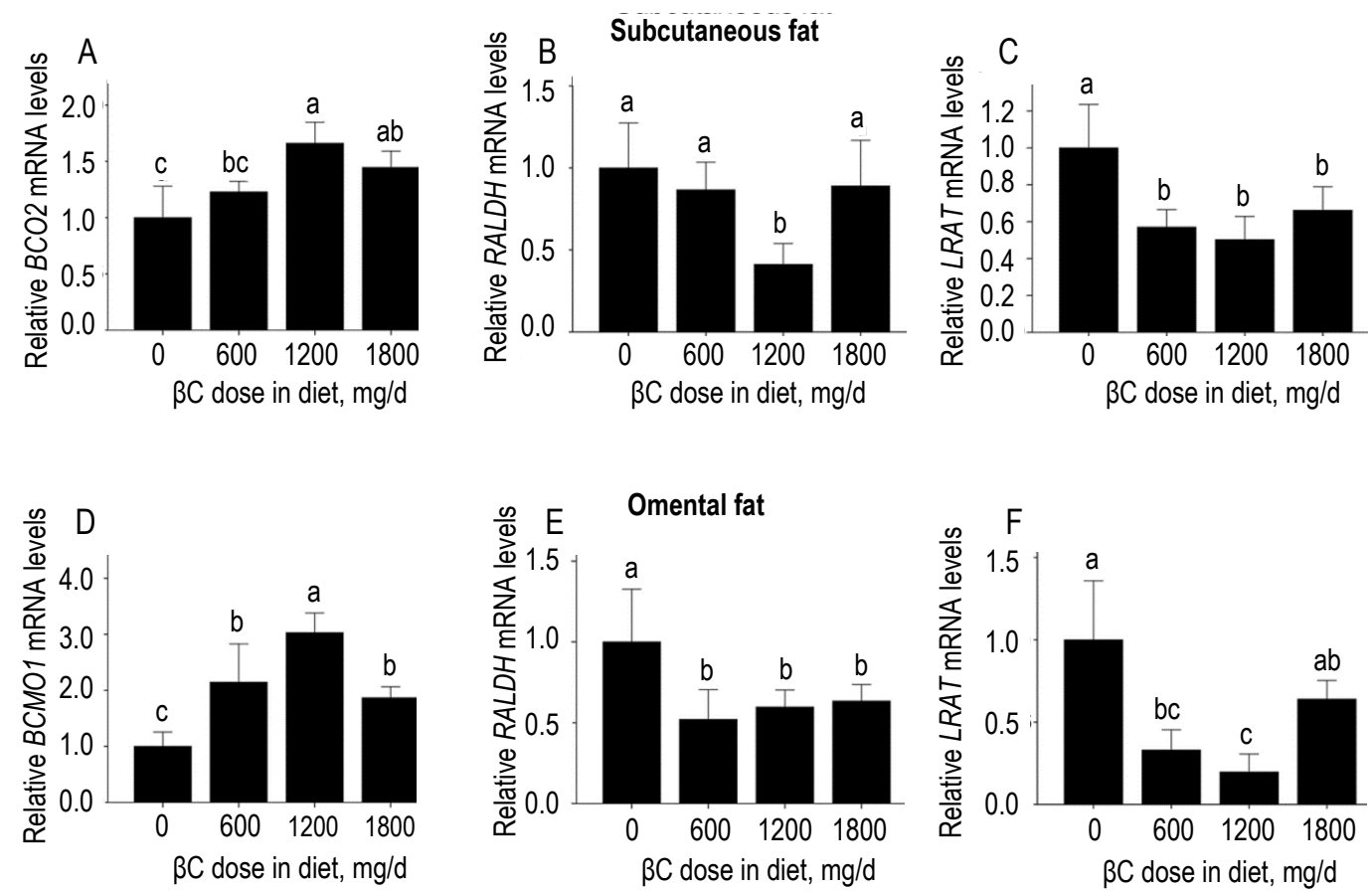

Figure 4. Expression of $B C O 2$ ( $A$ and $D), R A L D H(D$ and $E$ ) and $L R A T$ ( $C$ and $F$ ) in subcutaneous and omental fat, respectively, of beef cattle fed different amounts of $\beta$-carotene $(\beta C)(0,600,1200$ and $1800 \mathrm{mg} / \mathrm{d})$; bars present means \pm standard error $(\mathrm{SE})$, for 10 steers per group; a-C - bars with different superscripts vary significantly $(P<0.05)$

A

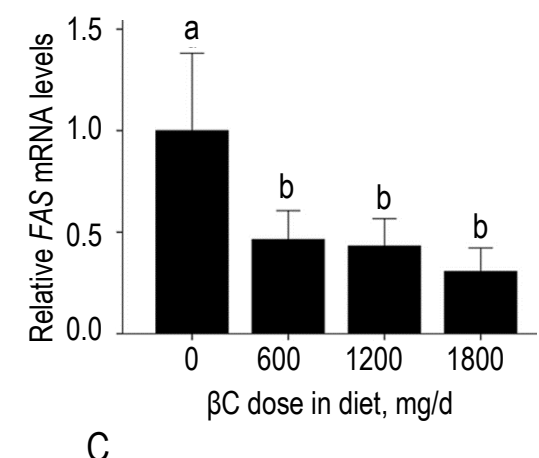

C

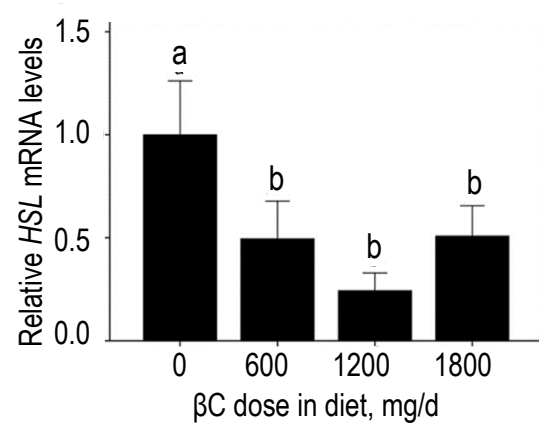

B
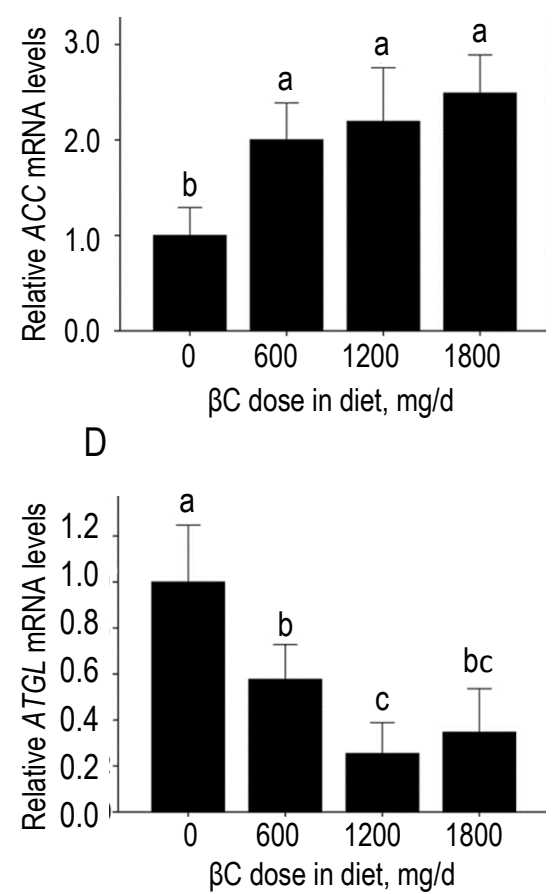

Figure 5. Expression of fat metabolism related genes (FAS (A), ACC (B), HSL (C) and ATGL (D)) in omental fat of beef cattle fed different amounts of $\beta$-carotene $(B C)(0,600,1200$ and $1800 \mathrm{mg} / \mathrm{d})$; bars present means \pm standard error $(S E)$, for 10 steers per group;. a- $-C-$ bars with different superscripts vary significantly $(P<0.05)$

tissue the LRAT expression was reduced in the $\beta \mathrm{C}$ supplemented groups at a dose of 600 and $1200 \mathrm{mg} / \mathrm{d}$ compared with the control group $(P<0.05$; Figure 4F).

\section{Expression of genes involved in lipid metabolism in omental adipose tissue}

In omental adipose tissue, the FAS and $H S L$ expression levels were significantly decreased in 
groups supplemented with $\beta C$ regardless its dose $(P<0.05$; Figure 5A and 5C). On the other hand, the $A C C$ expression was increased in all supplemented groups $(P<0.05$; Figure $5 \mathrm{~B})$. The expression of $A T G L$ was also down-regulated in the $\beta C$-treated groups; however the $A T G L$ expression in the group with supplementation at a dose of $1200 \mathrm{mg} / \mathrm{d}$ was significantly lower from the group with supplementation at a dose of $600 \mathrm{mg} / \mathrm{d}(P<0.05$; Figure 5D).

\section{Discussion}

There is growing evidence that acting as signalling molecules $\beta C$, VA and their derivatives can exert influence on adipocyte physiology by acting on parameters related to adiposity (García et al., 2009). Similarly, the effects of $\beta C$ supplementation on BCMO1, PPAR $\gamma$ and RXR $\alpha$ gene and protein expressions stated in the present study showed that there is a close relationship between carotenoids and fat metabolism in beef cattle, which was also found in our previous study (Jin et al., 2016). Adipose tissue was reported to be an important place for $\beta \mathrm{C}$ storage (Yang et al., 1992; Reynoso et al., 2004), which was also confirmed by our previous research (Jin et al., 2015). In the present study, the higher expression of $B C M O 1$ and $B C O 2$ in $\beta C$ supplemented groups in subcutaneous and omental adipose tissue may be caused by higher content of $\beta C$ reported by Jin et al. (2015), however the lack of differences among the supplemented groups may indicate a limited $\beta C$ metabolism capacity of adipose tissue.

Some papers demonstrated that dietary $\beta C$ has a repression effect on adipose tissue via $\mathrm{BCMO} 1$ (Amengual et al., 2011; Lobo et al., 2012), which was proposed to influence adipocyte physiology by contributing directly to VA production (Tourniaire et al., 2009). However, the results of the present study illustrated that supplementing $\beta C$ downregulated the VA anabolism related genes such as $R X R A, R A L D H$ and $L R A T$. It can be inferred that no inevitable connection exists between fat metabolism and VA generation. Furthermore, Ziouzenkova et al. (2007) reported that physiological concentration of retinal (one of the $\beta C$ conversion products) repressed lipogenesis in vitro and in vivo through inhibition of RXRA and PPARG activation via their respective ligands. In the present study, caused by $\beta C$ addition down-regulation of $R X R A$ and PPARG expression was accompanied by the down-regulated expressions of RALDH and LRAT, which was consistent with the lack of differences in VA content between $\beta C$ supplemented and control groups observed by Jin et al. (2015). Therefore, the repression effect of $\beta C$ on lipogenesis may be more related with $\beta C$ catabolism rather than VA andbolism.

Interestingly, our previous study showed that supplementing $\beta C$ up to $600 \mathrm{mg} / \mathrm{d}$ could increase concentrations of $\beta \mathrm{C}$ in subcutaneous and omental fat (Jin et al., 2015). Moreover in the present study the $\beta C$ supplementation up-regulated the two $\beta C$ catabolism related genes $\mathrm{BCMO1}$ and $\mathrm{BCO} 2$, which illustrates the capability of adipose tissues in $\beta C$ storage and catabolism.

For the lipid metabolism related genes, dietary $\beta C$ exerted reverse regulation effects on fat anabolism genes $F A S$ and $A C C$ in the omental fat. However, our previous results showed that in subcutaneous fat expression of both these genes was down-regulated in all group with $\beta C$ supplementation (Jin et al., 2016). So, it could be suggested that tissue-specific effects of $\beta C$ toward lipid metabolism related genes exist in beef cattle. The reverse effects of $\beta C$ on $F A S$ and $A C C$ expressions in the omental adipose tissue may shed new light on the result of Condron et al. (2014) who reported that omental adipose tissue (kidney, pelvic and heart fat) was not affected by dietary $\beta C$ addition up to $22000 \mathrm{IU} / \mathrm{kg}$.

\section{Conclusions}

Supplementation of $\beta$-carotene $(\beta C)$ in the diet may inhibit the expression of the major adipogenesis gene - PPARG and enhance the expression of $\beta \mathrm{C}$ catabolism involved genes in adipose tissue of beef cattle, which reflects a close connection between $\beta C$ and lipid metabolism. The effective dose of $\beta C$ to observed changes in $\beta C$, vitamin $A$ and lipid metabolism related genes expression would be at least $600 \mathrm{mg} / \mathrm{d}$.

\section{Acknowledgments}

This work was supported partly by Shandong Provincial Natural Science Foundation (ZR2017MC036), the National Natural Science Foundations of China (31601966), China Agriculture Research System (CARS-37), and Agricultural Science and Technology Innovation Project of Shandong Academy of Agricultural Sciences (CXGC2017B02, CXGC2018E10). These funders had no role in the design and analysis of the study or in the writing of this article.

\section{References}

Amengual J., Gouranton E., van Helden Y.G.J. et al., 2011. Betacarotene reduces body adiposity of mice via BCM01. PLoS ONE 6, e20644, https://doi.org/10.1371/journal.pone.0020644 
Boulanger A., McLemore P., Copeland N.G., Gilbert D.J., Jenkins N.A., Yu S.S, Gentleman S., Redmond T.M., 2003. Identification of beta-carotene 15,15'-monooxygenase as a peroxisome proliferator-activated receptor target gene. FASEB J. 17, 1304-1306, https://doi.org/10.1096/fj.02-0690fje

Condron K.N., Lemenager R.P., Claeys M.C., Lipkie T.E., Schoonmaker J.P., 2014. Supplemental $\beta$-carotene I: effect on plasma vitamin $A$, growth, performance, and carcass characteristics of feedlot cattle. Meat Sci. 98, 736-743, https://doi.org/10.1016/j.meatsci.2014.07.020

Feng Y.L., 2000. The Nutrient Requirements and Feeding Standards of Beef Cattle. China Agricultural University Press. Beijing (China)

García O.P., Long K.Z., Rosado J.L., 2009. Impact of micronutrient deficiencies on obesity. Nutr. Rev. $67,559-572$, https://doi. org/10.1111/j.1753-4887.2009.00228.x

Gong X., Tsai S.W., Yan B., Rubin L.P., 2006. Cooperation between MEF2 and PPARY in human intestinal $\beta, \beta$-carotene 15,15'-monooxygenase gene expression. BMC Mol. Biol. 7, 7, https://doi.org/10.1186/1471-2199-7-7

Gorocica-Buenfil M.A., Fluharty F.L., Reynolds C.K., Loerch S.C., 2007. Effect of dietary vitamin A concentration and roasted soybean inclusion on marbling, adipose cellularity, and fatty acid composition of beef. J. Anim. Sci. 85, 2230-2242, https:// doi.org/10.2527/jas.2006-780

Jin Q., Cheng H., Wan F., Bi Y., Liu G., Liu X., Zhao H., You W., Liu Y., Tan X., 2015. Effects of feeding $\beta$-carotene on levels of $\beta$-carotene and vitamin $A$ in blood and tissues of beef cattle and the effects on beef quality. Meat Sci. 110, 293-301, https://doi.org/10.1016/j.meatsci.2015.07.019

Jin Q., Zhao H.B., Liu X.M., Wan F.C., Liu Y.F., Cheng H.J., You W., Liu G.F., Tan X.W., 2016. Effect of $\beta$-carotene supplementation on the expression of lipid metabolism-related genes and the deposition of back fat in beef cattle. Anim. Prod. Sci. 57, 513-519, https://doi.org/10.1071/AN15434

Lafontan M., Langin D., 2009. Lipolysis and lipid mobilization in human adipose tissue. Prog. Lipid Res. 48, 275-297, https://doi. org/10.1016/j.plipres.2009.05.001

Liu X., Fu J., Song E., Zang K., Wan F., Wu N., Wang A., 2009. Effect of nicotinamide on proliferation, differentiation, and energy metabolism in bovine preadipocytes. Asian-Austral. J. Anim. 22, 1320-1327, https://doi.org/10.5713/ajas.2009.90091

Liu X., Liu G., Tan X., Zhao H., Cheng H., Wan F., Wu N., Song E., 2014. Gene expression profiling of SIRT1, FoxO1, and PPARy in backfat tissues and subcutaneous adipocytes of Lilu bulls. Meat Sci. 96, 704-711, https://doi.org/10.1016/j. meatsci.2013.09.019

Liu X., Zhao H., Jin Q., You W., Cheng H., Liu Y., Song E., Liu G., Tan X., Zhang X., Wan F., 2018. Resveratrol induces apoptosis and inhibits adipogenesis by stimulating the SIRT1AMPKa-FOXO1 signalling pathway in bovine intramuscular adipocytes. Mol. Cell Biochem. 439, 213-223, https://doi. org/10.1007/s11010-017-3149-z
Livak K.J., Schmittgen T.D., 2001. Analysis of relative gene expression data using real-time quantitative PCR and the $2^{-\Delta \Delta(C t)}$ method. Methods 25, 402-408, https://doi.org/10.1006/ meth.2001.1262

Lobo G.P., Amengual J., Palczewski G., Babino D., von Lintig J., 2012. Mammalian carotenoid-oxygenases: key players for carotenoid function and homeostasis. Biochim. Biophys. Acta 1821, 78-87, https://doi.org/10.1016/j.bbalip.2011.04.010

Mezaki Y., Fujimi T.J., Senoo H., Matsuura T., 2016. The coordinated action of lecithin: retinol acyltransferase and cellular retinolbinding proteins for regulation of vitamin $\mathrm{A}$ esterification. Med. Hypotheses 88, 60-62, https://doi.org/10.1016/j. mehy.2016.01.013

Reynoso C.R., Mora O., Nieves V., Shimada A., González de Mejía E., 2004. $\beta$-carotene and lutein in forage and bovine adipose tissue in two tropical regions of Mexico. Anim. Feed Sci. Technol. 113, 183-190, https://doi.org/10.1016/j. anifeedsci.2003.11.007

Schoof E., Stuppy A., Harig F., Carbon R., Horbach T., Stohr W., Rascher W., Dotsch J., 2004. Comparison of leptin gene expression in different adipose tissues in children and adults. Eur. J. Endocrinol. 150, 579-584, https://doi.org/10.1530/ eje.0.1500579

Shmarakov I.O., Yuen J.J., Blaner W.S., 2013. Carotenoid metabolism and enzymology. In: S.A. Tanumihardjo (Editor). Carotenoids and Human Health. Humana Press. Springer Science+Business Media. New York, NY (USA), pp. 29-56, https://doi.org/10.1007/978-1-62703-203-2

Siebert B.D., Kruk Z.A., Davis J., Pitchford W.S., Harper G.S., Bottema C.D.K., 2006. Effect of low vitamin A status on fat deposition and fatty acid desaturation in beef cattle. Lipids 41 , 365-370, https://doi.org/10.1007/s11745-006-5107-5

Tourniaire F., Gouranton E., von Lintig J., Keijer J., Luisa Bonet M., Amengual J., Lietz G., Landrier J.-F., 2009. $\beta$-Carotene conversion products and their effects on adipose tissue. Genes Nutr. 4, 179, https://doi.org/10.1007/s12263-0090128-3

Yang A., Larsen T.W., Tume R.K., 1992. Carotenoid and retinol concentrations in serum, adipose tissue and liver and carotenoid transport in sheep, goats and cattle. Aust. J. Agric. Res. 43, 1809-1817, https://doi.org/10.1071/AR9921809

Zimmermann R., Strauss J.G., Haemmerle G. et al., 2004. Fat mobilization in adipose tissue is promoted by adipose triglyceride lipase. Science 306, 1383-1386, https://doi. org/10.1126/science. 1100747

Ziouzenkova O., Orasanu G., Sukhova G., Lau E., Berger J.P., Tang G., Krinsky N.I., Dolnikowski G.G., Plutzky J., 2007. Asymmetric cleavage of $\beta$-carotene yields a transcriptional repressor of retinoid $X$ receptor and peroxisome proliferatoractivated receptor responses. Mol. Endocrinol. 21, 77-88, https://doi.org/10.1210/me.2006-0225 